\title{
Assessed Result Relationship Comment
}

National Cancer Institute

\section{Source}

National Cancer Institute. Assessed Result Relationship Comment. NCI Thesaurus. Code C94172.

Additional description of the assessed result relationship. 